\title{
MANAGEMENT ROLE IN DEVELOPMENT OF TOURISM, KOSOVO CASE
}

DOI: http://dx.doi.org/10.18509/GBP.2015.45

UDC: 338.486.2:005(497.115)

\author{
Halil Halili \\ MEDITERAN University, Kosovo
}

\begin{abstract}
ABSTRAKT
Tourism really is one of the industries which in recent years has increased the fastest in the world. Such a rapid development has resulted in the creation of high profits from the export of tourist services, thus contributing to the economic growth of various countries. But Tourist promotion bid can not be imagined without proper management, especially without the knowledge and skills that managers need to possess, it is not possible to manage effectively business organizations and regional and local self - government. There is a special role for the knowledge and skills of the managers, therefore creative and innovative manager is a key factor which has great influence in creation of the competitive advantages of the tourist organization. Developing Tourism Management requires total investment, long-term planning, professional staff who will guide and manage training programs Tourist Destinations.
\end{abstract}

Keywords: Management, Tourism, Development

THE ROLE OF MODERN MANAGEMENT IN DEVELOPMENT OF TOURISM In accordance with the changing needs of consumers of modern tourism product, it is necessary that the tourist offer to be more diverse in terms of eco-tourism, cultural tourism, health tourism, sports and thematic tourism nature and water tourism, especially in complemented regarded to many types of tourism in a single product.In this case the fast way of completion and diversification of tourism offer is evident .Therefore, is presented the obligation to know the modern management because of its role in development of tourism that reflects in all conducted research in the area of tourism. Tourist organizations and institutions must continuously monitor all the factors affecting tourism requests. Planning and development of tourist offer requires good knowledge of all the elements of tourism offer and request. In tourism contemporary (modern), many activities which until recently had only a supporting role, complementary, in the selection of tourist offer, example sports activities, recreational etc. Now, in a large measure are the main reason for choosing a tourist destination ${ }^{24}$. The management of destination is a term used to cover all ways of the impact of tourism in destination. It covers the planning and control of tourism and infrastructure development, visitor management, marketing, information in supporting business, setting and controlling and monitoring standards. Destination resort is ${ }^{25}$ "One of the elements of the tourism system, one that encourages the function of the entire system, attracts tourists and motivates their arrival, and connects all its elements". To become a space (place) tourist destination "is not crucial its size or geopolitical boundaries, but it is important the ability to attract tourists and completion of the complex tourist request".

\footnotetext{
${ }^{24}$ Udhëzues mbi zhvillimin e qëndrueshëm te Turizmit në Shqipëri, Dhoma e Tregtisë dhe Industrisë, Departamenti i Projekteve, Tiranë.

${ }_{25}$ (Križman-Pavlović, Živković, 2008, 100).
} 
Picture No.1: Integrated tourist destination management ( Bartoluci, Cavlek i suradnici, 2007, 45) ${ }^{26}$

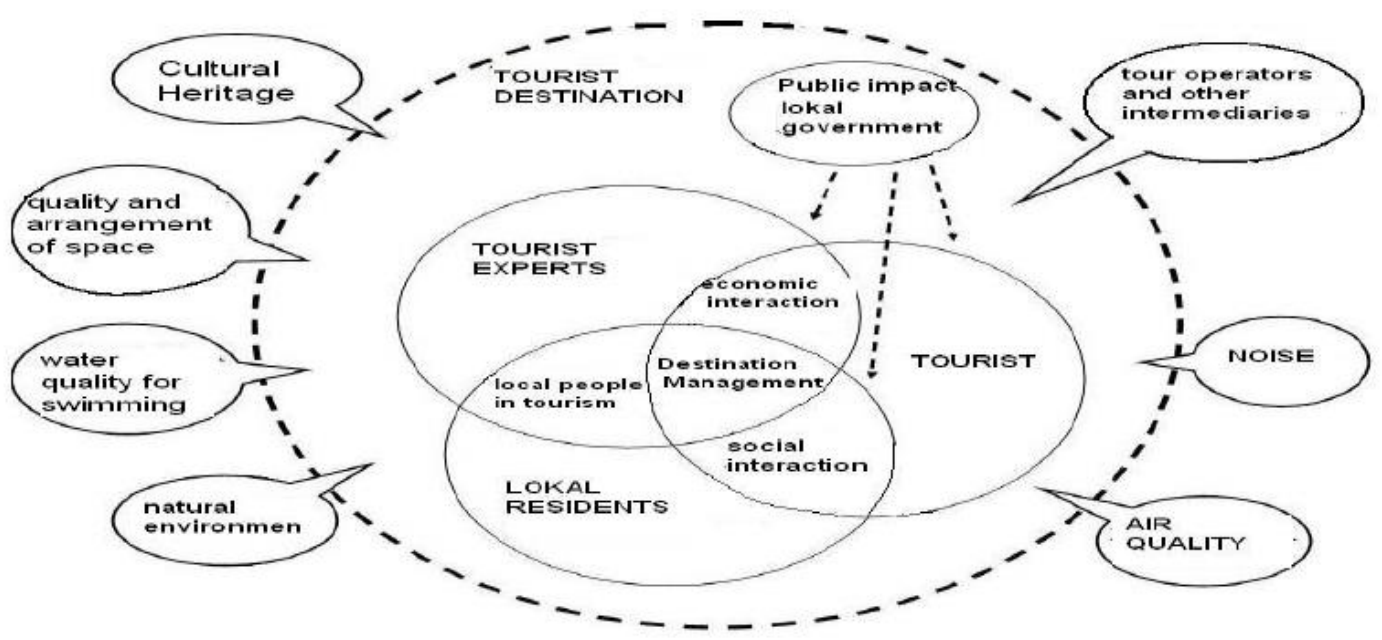

The role and the way of managing the destination of tourism significantly affects the development of tourism especially the increasement of the request. It is necessary to take care in selecting the elements that are within the tourism system involved in the management of tourist destinations, destination management specifically, how and in what extent the macro management determines opportunities of development at the micro level, saying in other way it is a development in a level of business organization.${ }^{27}$ The European Commission in 2003 issued "Guidelines for the evaluation and quality indicators of tourist destinations and services" which is interprets the concept of integrated management of tourist destination as the base for successful management. Based on it, it is clear the necessity of connectivity between all the different elements of the tourist destination management in order to finally achieve the expected benefits. ${ }^{28}$ Traditional access uncoordinated and single sector is insufficient to withstand the multiple demands of residents, visitors and businesses. The practice of integrated tourism management confirms theoretical statements of necessary knowledge and skills of modern managers, thus, ${ }^{29}$ "the manager needs to be positioned as a leader, human resource which will support the concept of integrity and work on the relationship and adapting to the needs and desires of tourists, local residents, all participants in the tourist offer, but also the authorities (local government) in the level of tourist destination ". It has be noted that the quality of provided service depends on the satisfaction of tourists, which will affect the willingness of tourists to stay or to return to the destination, but also in the structure and level of consumption of tourists.

${ }^{30}$ Scott (2008) has noted three elements that must to be taken into consideration for the knowledge about effective management in a destination: One, The understatement to adapt the knowledge of the managemnet in networks of SME- s tourist destination, two

\footnotetext{
${ }^{26}$ Mujo Dacic, The role of Management in development of sport and recreational programs in tourism, Regional Science conference with international participation, 03 -04june, 2011, Peja, Republic of Kosoa, yare 1, No. 1.

${ }^{27}$ A Manual for Evaluating the Quality Performance of Tourist Destinations and Services, ISBN, European Communities, 2003.

${ }^{28}$ Menaxhimi I Integruar i Qyteteve Historike, Udhëzues për Evropën Juglindore, Nëntor 2012;

${ }^{29}$ Magas, Persiç, 2007, 45;

${ }^{30}$ The Role of Knowledge-based Networks in Sustainable Tourism Development - A Conceptual Framework, Ehsan Ahmed and Larry Dwyer.
} 
development of strategies to increase hiring, transfer and dissemination of knowledge and three use of stakeholders and social networks to understand better trends and adapt knowledge within the destination.

The second element that is highlighted as an essential part of modern management it is a planning function. To ensure a qualified offer in tourism, it is necessary to be done in advance a qualified touristic plan. Special emphasis on the process of drafting the business plan of any organization, including tourist organizations, have put on the need for market knowledge, marketing and financial evaluation of the effectiveness of the project. Dynamic changes in the environment, then the need for better regulation of business organization, in the new market conditions, they contribute to the perception of the market as the dominant feature of the business. In literature, in different ways $d$ marketing is defined as a science, concept, business philosophy or a way of making business.

${ }^{31}$ Kotleri emphasizes the need for a different concept of marketing and defines it as: "a social process and controlled through which individuals and groups take what they need and want through creating and exchanging products and values with others". ${ }^{32}$ Marketing in the tourism industry is characterized by many specifics that come from supplies ,purchase, consummation and specific requirements of tourism. However marketing in tourism applies "general postulates of marketing activities under special conditions in which interact elements of trade in tourism ". The essence of marketing involves the notion of the market, therefore the knowledge of trade, especially the needs and demands of tourists coming from developed markets, creates a prerequisite of qualified plan of marketing activities. The planning of marketing activities is a process through which the organization predicts future market events and defines the way to achieve its marketing goals. Through Marketing Planning Organization creates the possibility to adapt to changes in the environment, visualize changes and respond to them in time. Marketing of tourist business organizations and planning of marketing activities should be explored in parallel with the marketing of tourist destinations, it's because tourism market organizations offer their products and services, as well as other holders of tourism marketing (non-profit organizations state or tourist destinations). It's challenge before marketing of the tourist destination that is reflected through the optimism of tourism impacts ( the best way of use of tourism impact ) and achievment of strategic goals. This task is difficult because ${ }^{33}$ different stakeholders tourist destinations (visitors, local residents, public sector, hospitality companies and others) are involved in product development and production of tourist destination, and that often have different interests even are in conflict. Managers who manage tourism businesses and public sector organizations before making a work plan, especially in a marketing segment, should think about marketing in a new way.

\footnotetext{
${ }^{31}$ Kotler, (2007, 6 );

${ }^{32}$ Križman, 1998, 43-51;

${ }^{33}$ Buhalis, 2000, 98)
} 


\section{HUMAN RESOURCES FOR TOURISM}

The current situation on the capacity of human resources in the tourism sector

Tourism Human resources for tourism constitute one of the most important issue that a tourist destination should have consideration for the development of tourism. Praising data that are provided in 2012 were 3.715 active enterprises such as hotels, restaurants, etc ${ }^{34}$.

\section{The insurance of education and trainings related to tourism}

Education providers of it and professional trainings are mainly Professional Secondary schools and Universities.

Secondary professional schools that offer training in hospitality - tourism in Kosovo are: - the Secondary school of Tourism-Hospitality "17 September" Pristina, the field of Tourism, profile Assistant in restaurant, chef, Confectionery, Assistant to the hotel and tourism assistant;

- the Economic Secondary School "Isa Boletin" Besian, the field of Economics, profile, Assistant to the hotel;

- the Economic Secondary School "Ali Hadri" Peja, the field of Economics, profile, Assistant in the hotel in Bosnian language;

- the Economic Secondary School "Ymer Prizren" Prizeren, the field of Economics, profile, Assistant in the restaurant in Bosnian language;

- the Economic Secondary School "Marin Barleti" Gjilan, the field of Economics,profile, Assistant to the hotel

- the Economic Secondary school "Faik Konica" Ferizaj, the field of Economics, profile, Assistant to the hotel;

- the Economic Secondary School "K. Kusari "Gjakov, the field of Economics, profile

, Resort Assistant ;

- the Secondary mixed school "Rushd Berisha" Dragas field Economics, Assistant to the hotel profile;

- the Secondary mixed school, Viti, field of Economics, profile,Assistant to the hotel ;

From this we can conclude that the average number of classes in the first year of registration is in total of 12 classes, with approximately 360 students. In fact that upper secondary education in Kosovo lasts 3 years then we can conclude that we currently have 1080 secondary school students. Public universities that offer courses on tourism management are as following:

University "Haxhi Zeka" in Peja, Faculty of Management in Tourism, Hospitality and Environment offers Bachelor and Master programs;

Private University College "Budi" which has also two programs, Bachelor and Master in directions Tourism \& Hospitality Management;

Also some other public universities but also private colleges have in their programs courses of tourism, and they have developed tourism curricula.

I think these two faculties play an active role in promoting tourism education in Kosovo, although the results are not yet visible in the market.

Professional trainings through donor projects. Through various projects donors are provided short-term trainings in several areas in the country, that cover issues such as:

\footnotetext{
${ }^{34}$ Agjencia e Statistikave të Kosovës, Rezultatet e Anketes Strukturore të Ndërmarrjeve 2008-2012, f11
} 
Tourist Guide Training of Trainers (ToT) in relation to hospitality, various aspects of the line level employees in hotels and restaurants, inns (host homes, etc.).

\section{Compliance situation of offer and request}

The current system of education and tourism curricula do not accomplish the requirements for quality and quantity tourism industry. University courses are mainly theoretical and lose professional orientation and practical and thus do not comply with the requirements of the industry. With a limited number of jobs in public administration and managerial positions in the private sector, graduated students of tourism branches are not involved in occupations in the tourism sector.

\section{POLICIES FOR THE DEVELOPMENT OF HUMAN RESOURCES}

The analysis of human resources (personnel of tourism) showed a small part of employment in this sector compared to the total number of employees - only $5.1 \%$ (2012).Also, the analysis showed unfavorable educational structure of full-time employees. Tourism as a strategic orientation of the development of the Republic of Kosovo requires a suitable policy in the field of education and culture.

\section{Education}

For different levels of education it is required different access to tourism, as for the role of education and teaching, as well as for the development of it . In the field of primary education, for the curriculum structure it is necessary:

- to develop the conscience of tourism as a potential industry that will be the base for socio-economic progress of the population;

- Through relevant subjects and their content (biology, ecology, geography, chemistry ...) to develop an environmental conscience of young people, to build an active and responsible attitude towards the environment.

In the field of secondary education it is necessary :

To create a network of educational institutions (schools of hospitality and tourism) that will be at the service of tourism development at the regional level;

In educational curricula to include a necessary number of subjects that will affect the raise of the general level of culture and the raise of opportunities in communications ( to include at least two foreign languages in all educational programs, for all the years of studies in secondary schools.)

- Special attention to the waiters and their practical teaching also for the people that cook food. (Cook- chef). To add classes for practice in the last two years of education cycle and to be directed and supervised by prominent professionals, respective facilities or educational institutions in panel of tourism or specific resorts companies.

In the sphere of higher education in the respective programs of study, tourism, hotel management, economics, agriculture, then geography, biology, spatial planning is necessary:

To train potential participants in the tourism industry for the general standing, competent and active towards the environment;

To train potential participants in the tourism industry for the positioning of tourism in the model of sustainable development;

To plan a network of state institutions of higher education that will produce highly educated personnel in tourism, hotels and gastronomy; 
Curriculums special profiles to fit study plans and programs of countries with developed tourism from the neighborhood and beyond;

To ensure licensing and accreditation of all educational institutions of higher education in the Republic of Kosovo in the field of tourism and hotel resorts, from the appropriate experts national and international.

\section{Culture}

The culture of life and communication it is an integral part of the tourism product and an essential prerequisite for the development of tourism. This field it will have progress by improving the educational system and general conditions of socio-economic development. Cultural dimension is defined by different impacts. Development of tourism, among others, is also based on the cultural offer in the field of spiritual and material creativity. Stimulating cultural creativity, in fact, promotes and stimulate tourism products and tourism of a tourist destination. The main carriers of culture in tourism are: Tourism Organization, tourism companies and associations, commercial tourist operators and cultural institutions.

Coherence and institutional competence of the participants in the tourism industry constitute a precondition for organized tourist offer and improvement of the tourism product. Financial support for the leaders of culture and cultural life in tourist destinations is a impeller to improve cultural products and to achieve an organized touristic offer .

\section{CONCLUSION}

Considering the fact that the Management for years in the industry of tourism had only a secondary role, as a supporter of the objectives, in the new concept of modern tourism is evident the necessity, that besides the new concept of tourism the modern management it has to evolve. So management is becoming an important element of the development of tourist destinations. The role of management at all levels, both in terms of tourist business organizations, local community or state, is essential to the creation and management of tourist programs (tourist offer). Based on proven research it is believed that modern management plays a key role in the development of tourism, development of tourist destination. Tourism in Kosovo is an important segment of the economy so the approval of the Law of Tourism ${ }^{35}$, and the Decision to form the Kosovo Tourism Council ${ }^{36}$, should see as an awareness of the importance of tourism to the economic development of Kosovo. It should especially be noted that it is time to invest in new programs in tourism, advancing the tourist offer (development of a comprehensive offering Kosovo tourism that will highlight the complementarily of the mountain and medical tourism and on the other hand the rich heritage and cultural diversity and historical) and with this increasing the Touristic Modern Management .

Particular attention should be given to a specific orientation Diaspora investments and FDI (Foreign Direct Investment) in Tourism, from which Kosovo Tourism investment has the opportunity to develop itself and improve its range of destinations and in this way to contribute to general economic development of Kosovo.

\footnotetext{
${ }^{35} \mathrm{http}: / /$ gazetazyrtare.rks-gov.net/GZ2013.aspx

${ }^{36} \mathrm{http}: / /$ www.kryeministri-ks.net/?page $=1,5$
} 


\section{REFERENCES}

[1] A Manual for Evaluating the Quality Performance of Tourist Destinations and Services, ISBN, European Communities, 2003;

[2] Buhalis, D., 2000, Relationships in the distribution channel of tourism: Conflicts between hoteliers and tour operators in the Mediterranean region, International Hospitality, Leisure and Tourism;

[3] Kotler, Ph. (2006). Osnove marketinga, Mate: Zagrebačka škola ekonomije i menadžmenta, Zagreb;

[4] Križman D., Živolić S. (2008). Upravljanje marketingom turističke destinacije:stanje i perspektive u Republici Hrvatskoj, Ekonomska istraživanja , Vol.21 (2008) No.2 (99-113);

[5] Magaš, D.(2003) Menadžment turističke organizacije $i$ destinacije, Opatija: Fakultet za turistički i hotelski menadžment Opatija

[6] Menaxhimi i Integruar i Qyteteve Historike, Udhëzues për Evropën Juglindore, Nëntor 2012;

[7] The Role of Knowledge-based Networks in Sustainable Tourism Development A Conceptual Framework, Ehsan Ahmed and Larry Dwyer;

[8] Udhëzues mbi zhvillimin e qëndrueshëm te Turizmit në Shqipëri, Dhoma e Tregtisë dhe Industrisë, Departamenti i Projekteve, Tiranë;

[9] http://gazetazyrtare.rks-gov.net/GZ2013.aspx

[10] http://www.kryeministri-ks.net/?p. 
